\title{
Secretions from the ventral eversible gland of Spodoptera exigua caterpillars activate defense- related genes and induce emission of volatile organic compounds in tomato, Solanum lycopersicum
}

\author{
Simon Zebelo*, Jill Piorkowski, Joseph Disi and Henry Fadamiro
}

\begin{abstract}
Background: Plant induced defense against herbivory are generally associated with metabolic costs that result in the allocation of photosynthates from growth and reproduction to the synthesis of defense compounds. Therefore, it is essential that plants are capable of sensing and differentiating mechanical injury from herbivore injury. Studies have shown that oral secretions (OS) from caterpillars contain elicitors of induced plant responses. However, studies that shows whether these elicitors originated from salivary glands or from other organs associated with feeding, such as the ventral eversible gland (VEG) are limited. Here, we tested the hypothesis that the secretions from the VEG gland of Spodoptera exigua caterpillars contain elicitors that induce plant defenses by regulating the expression of genes involved in the biosynthesis of volatile organic compounds (VOCs) and other defense-related genes. To test this hypothesis, we quantified and compared the activity of defense-related enzymes, transcript levels of defense-related genes and VOC emission in tomato plants damaged by S. exigua caterpillars with the VEG intact (VEGI) versus plants damaged by caterpillars with the VEG ablated (VEGA).

Results: The quantified defense-related enzymes (i.e. peroxidase, polyphenol oxidase, and lipoxigenase) were expressed in significantly higher amounts in plants damaged by VEGI caterpillars than in plants damaged by VEGA caterpillars. Similarly, the genes that encode for the key enzymes involved in the biosynthesis of jasmonic acid and terpene synthase genes that regulate production of terpene VOCs, were up-regulated in plants damaged by VEGl caterpillars. Moreover, the OS of VEGA caterpillars were less active in inducing the expression of defense genes in tomato plants. Increased emissions of VOCs were detected in the headspace of plants damaged by VEGI caterpillars compared to plants damaged by VEGA caterpillars.
\end{abstract}

Conclusion: These results suggest that the VEG of S. exigua caterpillars contains elicitors of late plant defense signaling in tomato which trigger defense-related enzymatic activity, regulate expression of defense-related genes, and induce emission of plant VOCs. These signaling cascades may have important ramifications for plant-insect and tritrophic interactions.

Keywords: VEG, Enzymatic activity, VOCs, Defense-related genes

\footnotetext{
* Correspondence: saz0002@auburn.edu

Department of Entomology \& Plant Pathology, Auburn University, Auburn, AL 36849, USA
}

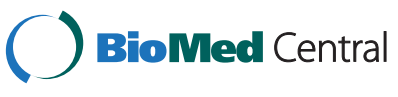

(c) 2014 Zebelo et al.; licensee BioMed Central Ltd. This is an Open Access article distributed under the terms of the Creative Commons Attribution License (http://creativecommons.org/licenses/by/2.0), which permits unrestricted use, distribution, and reproduction in any medium, provided the original work is properly credited. The Creative Commons Public Domain Dedication waiver (http://creativecommons.org/publicdomain/zero/1.0/) applies to the data made available in this article, unless otherwise stated. 


\section{Background}

Plants have evolved to defend themselves against biotic stressors such as insects and pathogens. Various insect secretions including oviposition fluids, oral secretions (OS), and insect excreta are known to act as elicitors of induced plant defenses against insect herbivory [1-5]. Plant defense signaling cascades induced by insects begin with plant recognition of insect-derived elicitors followed by plasma trans-membrane potential $\left(\mathrm{V}_{\mathrm{m}}\right)$ depolarization [6-8], the rise in cytosolic calcium ions [9] and a burst of reactive oxygen species (ROS), including hydrogen peroxide $\left(\mathrm{H}_{2} \mathrm{O}_{2}\right)$ and nitric oxide (NO) $[2,10,11]$. These cascades lead to a rise in production of the phytohormone, jasmonic acid (JA) and salicylic acid (SA) [3,12] that regulate the transcript level of defense-related genes $[3,13]$, and end with metabolic changes including release of volatile organic compounds (VOCs) [1,3,13-15] and production of toxic compounds in the plants [16,17]. Plasma trans-membrane potential $\left(\mathrm{V}_{\mathrm{m}}\right)$ depolarization, rise in cytosolic calcium ions and a burst of reactive oxygen species (ROS) which occurs from seconds to hour/s after insect damage referred to as early plant defense responses, while production of the phytohormone, change in transcript level of defense-related genes and metabolic changes including release of VOCs and production of toxic compounds which occurs from hour/s to day/s after insect damage referred to as late plant defense responses [18].

Foliar feeding insects ingest leaves by snipping plant material continuously. This process causes a series of mechanical injury, usually supplemented with introduction of oral secretions into the damaged tissue $[1,3,4,10,18,19]$. It is vital for plants to differentiate mechanical injury from herbivore damage and change these different biotic stress signals into suitable physiological responses. Studies have shown that plants are able to differentiate simple mechanical injury from herbivore injury [6,10,20-25]. Investigations at the molecular level have revealed different gene expression patterns of defense-related genes in plants with mechanical injury versus plants damaged by insects [6,20-25]. Application of insect OS to mechanical injury can mimic most plant responses to herbivory $[6,22,26]$, showing that the OS constitute elicitors by which plants recognize insect attack $[3,6,26,27]$. Indeed, several elicitors have been isolated from insect OS that trigger plant defenses against herbivory, such as $\beta$-glucosidase [15], volicitin, a fatty acid-amino acid conjugate [1,28,29], caeliferins [30], and inceptins [25]. Lepidopteran OS consists of saliva from mandibular and labial secretions, and regurgitant from digestive tract [19,31]. The OS deposited on herbivore fed plant material also contains secretions from the ventral eversible gland (VEG) [32]. Despite the discovery of several elicitors, studies that show whether these elicitors originated from salivary glands or from other organs associated with feeding, such as the ventral eversible gland (VEG) are limited.
Volicitin originated from the gut tissues of Spodoptera litura larvae [33] and inceptins are partially digested chloroplast protein formed when Spodoptera frugiperda attack cowpea [25].

The VEG is a secretory structure found on the ventral surface of the thorax of caterpillars (lepidopteran larvae). It consists of two regions with different functions: a noneversible glandular sac lined with secretory cells and an eversible cuticular tube. Eversion of the cuticular tube forms a visible papilla, whereas secretions from the secondary gland area on the cuticular tube are transferred to the apex of the papilla and released [34]. Since the tip of the everted VEG can reach the mandibles [35], its secretions are deposited onto the food substrate with the OS [32]. Secretions from the VEG of caterpillars have been associated with defense against predators and the production of anti-aggregation pheromones [34-36]. However, the role of VEG secretions in plant-insect interactions remains unclear. Recently, Zebelo and Maffei [32] demonstrated that secretions from the VEG of Spodoptera littoralis caterpillars trigger early defense signaling events in Arabidopsis thaliana.

In the present study, we investigated possible involvement of VEG secretions from $S$. exigua caterpillars in the induction of late defense signaling in tomato. We quantified and compared the activity of defense-related enzymes, transcript levels of terpene synthase genes and other defense-related genes, and VOC emission in tomato plants damaged by $S$. exigua caterpillars with the VEG intact (VEGI) versus plants damaged by caterpillars with the VEG ablated (VEGA) as well as mechanically injured plants treated with OS from VEGI caterpillars (MI + OSVEGI) versus mechanically injured plants treated with $\mathrm{OS}$ from VEGA caterpillars (MI + OSVEGA).

\section{Results}

\section{VEG ablation didn't affect S. exigua feeding activity}

Before we started to assess the impact of VEG secretions on triggering plant defense, we evaluated whether VEG ablation affects feeding activity of $S$. exigua caterpillars. There were no significant differences between VEGA $\left(2.42 \pm 0.44 \mathrm{~cm}^{2}\right)$ and VEGI $\left(2.61 \pm 1.04 \mathrm{~cm}^{2}\right)$ caterpillars on leaf area consumption after $24 \mathrm{~h}(\mathrm{P}>0.84)$.

\section{VEG secretions activate defense-related enzymes in tomato}

The selected defense-related enzymes, peroxidase (POD), polyphenol oxidase (PPO), and lipoxygenase (LOX), were expressed in significantly higher amounts in plants damaged by VEGI caterpillars and MI + OSVEGI than in plants damaged by VEGA caterpillars, mechanically injured (MI) plants, MI + OSVEGA plants, and untreated (control) plants. Activity of POD was significantly higher in VEGI-damaged and MI + OSVEGI tomato plants than in VEGA-damaged, MI, MI + OSVEGA or undamaged plants, 
starting as early as $24 \mathrm{~h}$ after treatment (Figure $1 \mathrm{~A}$ ). Activity of PPO $48 \mathrm{~h}$ after treatment was 8.2, 9.1, 8.8 and $8.5 \%$ higher in plants damaged by VEGI caterpillars than in plants damaged by VEGA caterpillars, MI, MI + OSVEGA, or undamaged plants, respectively (Figure 1B). A significant increase in LOX-specific activity levels was detected as early as $24 \mathrm{~h}$ after treatment in plants damaged by VEGI caterpillars and MD + OSVEGI plants compared to the other treatments. Activity of LOX $72 \mathrm{~h}$ after treatment was 14.2, 17, 14.6 and $21.6 \%$, higher in plants damaged by VEGI caterpillars than in plants damaged by VEGA caterpillars, MI, MI + OSVEGA, or undamaged plants, respectively (Figure 1C).
In general, no significant differences were recorded in enzymatic activity between plants damaged by VEGI caterpillars and MI + OSVEGI plants (Figure 1 and Table 1).

\section{VEG secretions induce VOCs emission in tomato}

Key differences were recorded in the headspace VOC profiles of tomato plants from the different treatments (Figure 2). Increased emission of VOCs was detected in the headspace of plants damaged by VEGI caterpillars compared to plants damaged by VEGA caterpillars, mechanically injured (MI) plants, and untreated (control) plants. Specifically, green leaf volatiles (GLVs) and
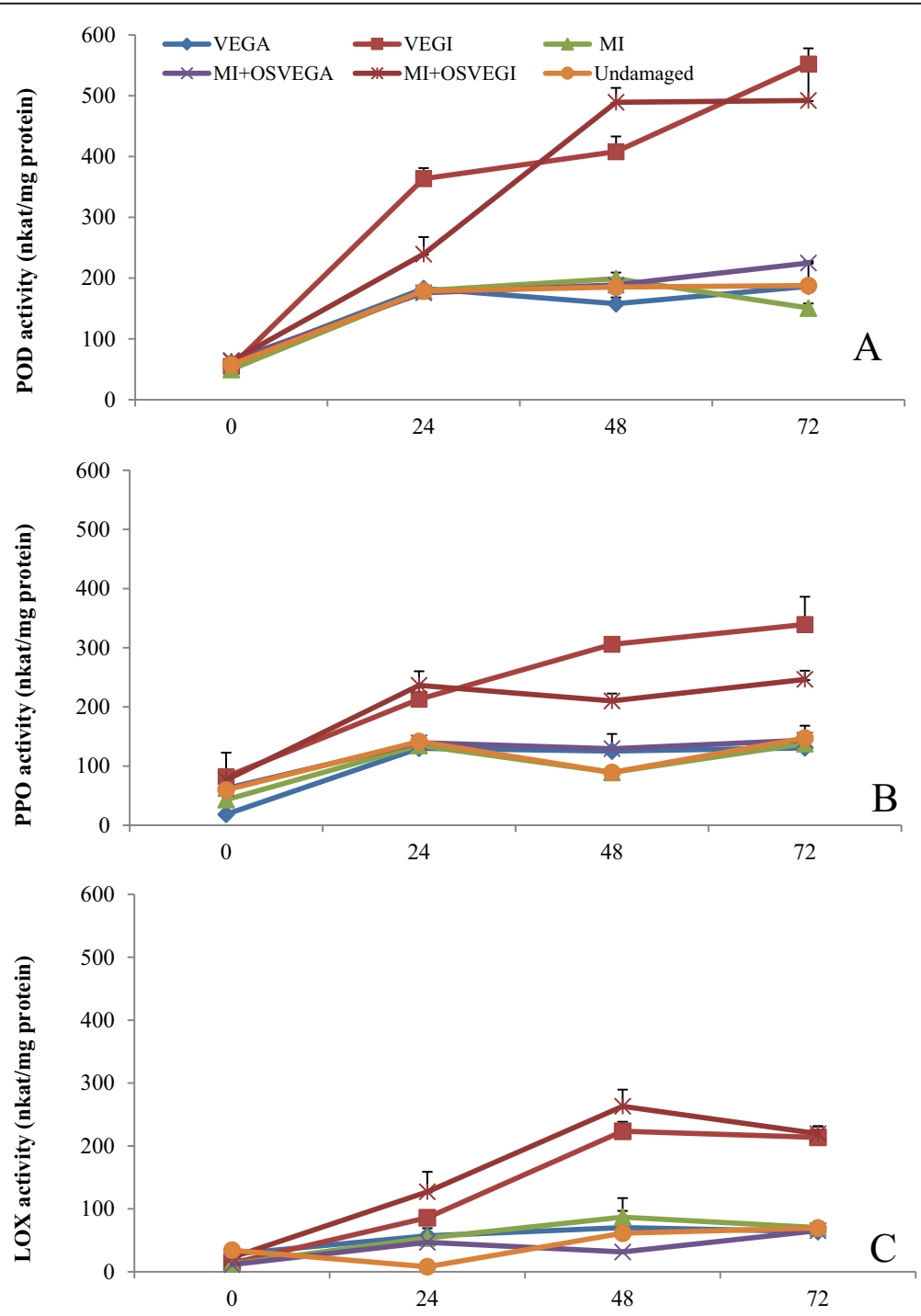

Figure 1 Secretions from the ventral eversible gland (VEG) of Spodoptera exigua caterpillars activate defense-related enzymes in tomato. Figure shows activity (expressed as mean \pm SEM nkat/mg protein) of three defense-related enzymes, (A) peroxidase (POD), (B) polyphenol oxidase (PPO), and (C) lipoxygenase (LOX), in leaves of tomato plants damaged by caterpillars with the VEG intact (VEGI), plants damaged by caterpillars with the VEG ablated (VEGA), mechanically injured (MI) plants, mechanically injured plants treated with oral secretion (OS) from VEGI caterpillars (MI + OSVEGI), mechanically injured plants treated with OS from VEGA caterpillars (MI + OSVEGA), and undamaged (control) plants, at 0, 24, 48 and $72 \mathrm{~h}$ after caterpillar feeding. Data were collected from three plants (i.e. 3 biological replicates) per treatment (see Table 1 for significant differences among treatments). 
Table 1 Levels of defense-related enzymes in tomato plants in response to six treatments

\begin{tabular}{|c|c|c|c|c|}
\hline \multirow{2}{*}{$\begin{array}{l}\text { Hours after } \\
\text { treatment }\end{array}$} & \multirow[t]{2}{*}{ Treatment } & \multicolumn{3}{|c|}{ Enzymatic activity (nkat/mg protein) } \\
\hline & & POD & PPO & LOX \\
\hline \multirow[t]{6}{*}{0} & VEGI & $55.29 \pm 2.95 a$ & $52.35 \pm 4.65 a$ & $13.54 \pm 0.66 a$ \\
\hline & VEGA & $61.17 \pm 1.35 \mathrm{a}$ & $58.23 \pm 0.89 a$ & $28.45 \pm 6.54 a$ \\
\hline & $\mathrm{Ml}+$ OSVEGI & $66.46 \pm 1.14 a$ & $56.42 \pm 2.80 a$ & $22.71 \pm 1.12 \mathrm{a}$ \\
\hline & $\mathrm{Ml}+$ OSVEGA & $64.60 \pm 4.38 a$ & $62.39 \pm 11.44 a$ & $11.20 \pm 0.88 a$ \\
\hline & $\mathrm{Ml}$ & $49.70 \pm 0.75 a$ & $59.25 \pm 5.49 a$ & $12.97 \pm 3.48 a$ \\
\hline & Undamaged & $56.48 \pm 1.14 \mathrm{a}$ & $60.51 \pm 3.47 a$ & $34.80 \pm 2.14 a$ \\
\hline \multirow[t]{6}{*}{24} & VEGl & $363.60 \pm 17.66 a$ & $212.08 \pm 20.20 b$ & $85.84 \pm 12.59 a$ \\
\hline & VEGA & $182.81 \pm 3.97 c$ & $130.06 \pm 8.76 c$ & $57.67 \pm 3.22 b$ \\
\hline & $\mathrm{Ml}+$ OSVEGI & $239.45 \pm 24.23 b$ & $236.78 \pm 23.97 a$ & $127.54 \pm 6.61 a$ \\
\hline & $\mathrm{Ml}+$ OSVEGA & $175.78 \pm 5.79 c$ & $139.45 \pm 4.65 c$ & $46.56 \pm 1.71 b$ \\
\hline & $\mathrm{Ml}$ & $179.29 \pm 21.89 c$ & $134.82 \pm 25.09 c$ & $53.33 \pm 5.24 b$ \\
\hline & Undamaged & $178.70 \pm 1.22 c$ & $141.43 \pm 6.76 c$ & $22.05 \pm 0.61 b$ \\
\hline \multirow[t]{6}{*}{48} & VEGl & $407.96 \pm 17.10 b$ & $305.29 \pm 17.47 a$ & $70.75 \pm 2.06 a$ \\
\hline & VEGA & $157.79 \pm 10.50 d$ & $125.63 \pm 22.31 c$ & $33.95 \pm 2.89 d$ \\
\hline & $\mathrm{MI}+$ OSVEGI & $489.27 \pm 23.70 a$ & $210.60 \pm 7.35 b$ & $57.06 \pm 2.70 b$ \\
\hline & $\mathrm{Ml}+$ OSVEGA & $188.80 \pm 11.67 c$ & $129.27 \pm 6.05 c$ & $17.17 \pm 2.22 \mathrm{c}$ \\
\hline & $\mathrm{Ml}$ & $199.16 \pm 10.30 c$ & $89.65 \pm 68.88 c$ & $31.18 \pm 5.37 d$ \\
\hline & Undamaged & $195.25 \pm 7.41 c$ & $89.63 \pm 17.64 c$ & $27.47 \pm 6.49 d$ \\
\hline \multirow[t]{6}{*}{72} & VEGl & $552.26 \pm 24.75 a$ & $339.99 \pm 21.92 \mathrm{a}$ & $213.67 \pm 35.32 \mathrm{a}$ \\
\hline & VEGA & $186.40 \pm 7.67 e$ & $130.76 \pm 24.01 \mathrm{c}$ & $63.78 \pm 8.84 b$ \\
\hline & $\mathrm{MI}+$ OSVEGI & $492.27 \pm 17.01 b$ & $246.12 \pm 15.96 b$ & $219.46 \pm 9.81 a$ \\
\hline & $\mathrm{Ml}+$ OSVEGA & $224.92 \pm 12.97 c$ & $143.74 \pm 8.34 c$ & $65.38 \pm 3.07 b$ \\
\hline & $\mathrm{Ml}$ & $150.80 \pm 8.22 d$ & $137.80 \pm 5.03 c$ & $70.18 \pm 1.85 b$ \\
\hline & Undamaged & $187.66 \pm 18.53 \mathrm{e}$ & $147.32 \pm 20.83 c$ & $69.45 .68 \pm 1.09 b$ \\
\hline
\end{tabular}

Table shows activity (expressed as mean \pm SEM nkat/mg protein) of three defense-related enzymes, peroxidase (POD), polyphenol oxidase (PPO), and lipoxygenase (LOX), in tomato plants damaged by caterpillars with the VEG intact (VEGI), plants damaged by caterpillars with the VEG ablated (VEGA), mechanically injured (MI) plants, mechanically injured plants treated with oral secretion (OS) from VEGI caterpillars (MI + OSVEGI), mechanically injured plants treated with OS from VEGA caterpillars (MI + OSVEGA), and undamaged (control) plants, at 0, 24, 48 and $72 \mathrm{~h}$ after caterpillar feeding. Data were collected from three plants (i.e. 3 biological replicates) per treatment. Means $( \pm$ SEM) within the same column and time period having different letters are significantly different $(P<0.05)$.

certain monoterpenes were emitted in higher amounts by plants damaged by VEGI caterpillars than in the other treatments (Figure 2, Table 2). In particular, the GLVs, (E)-2-hexenal, (Z)-3-hexenal, (Z)-3-hexenyl acetate and $(Z)$-2-hexenol were emitted in 7-fold, 5-fold, 7-fold and 10-fold, respectively, in plants damaged by VEGI caterpillars compared to plants damaged by VEGA caterpillars (Figure 2 and Table 2).

The monoterpenes, $\beta$-linalool and $\gamma$-terpinene, were emitted in significantly higher amounts by plants damaged by VEGI caterpillars compared to plants damaged by VEGA caterpillars and the other treatments (Figure 2, Table 2). However, no significant differences were recorded among the treatments in the emission of $\alpha$-pinene, $\beta$ phellendrene, $\beta$-pinene and $\beta$-ocimene. The sesquiterpenes, (E)- $\beta$-caryophyllene, $\alpha$-humulene and $\beta$-elemene, were also emitted in significantly higher amounts by plants damaged by VEGI caterpillars compared to the other treatments.
Furthermore, emission of the fatty acids (3-octanol, nonanal) and organic ester (methyl salicylate), was higher in VEGI-damaged plants (Figure 2 and Table 2).

\section{VEG secretions increase transcript levels of defense- related genes in tomato}

We used quantitative RT-PCR to quantify the transcript levels of six defense-related genes including genes encoding lipoxygenase $(L O X)$, allene oxide synthase $(A O S)$, and four genes involved in terpene biosynthesis (terpene synthase genes). $L O X$ and AOS are key enzymes in the jasmonic acid (JA) biosynthesis pathway. Most of defenserelated genes were found up-regulated in plants damaged by VEGI caterpillars and in MI + OSVEGI plants compared to plants damaged by VEGA caterpillars, mechanically injured (MI), MI + OSVEGA, or untreated (control) plants (Table 3). In particular, the transcript levels of the terpene synthase genes, TPS5 (encodes monoterpene synthesis) 


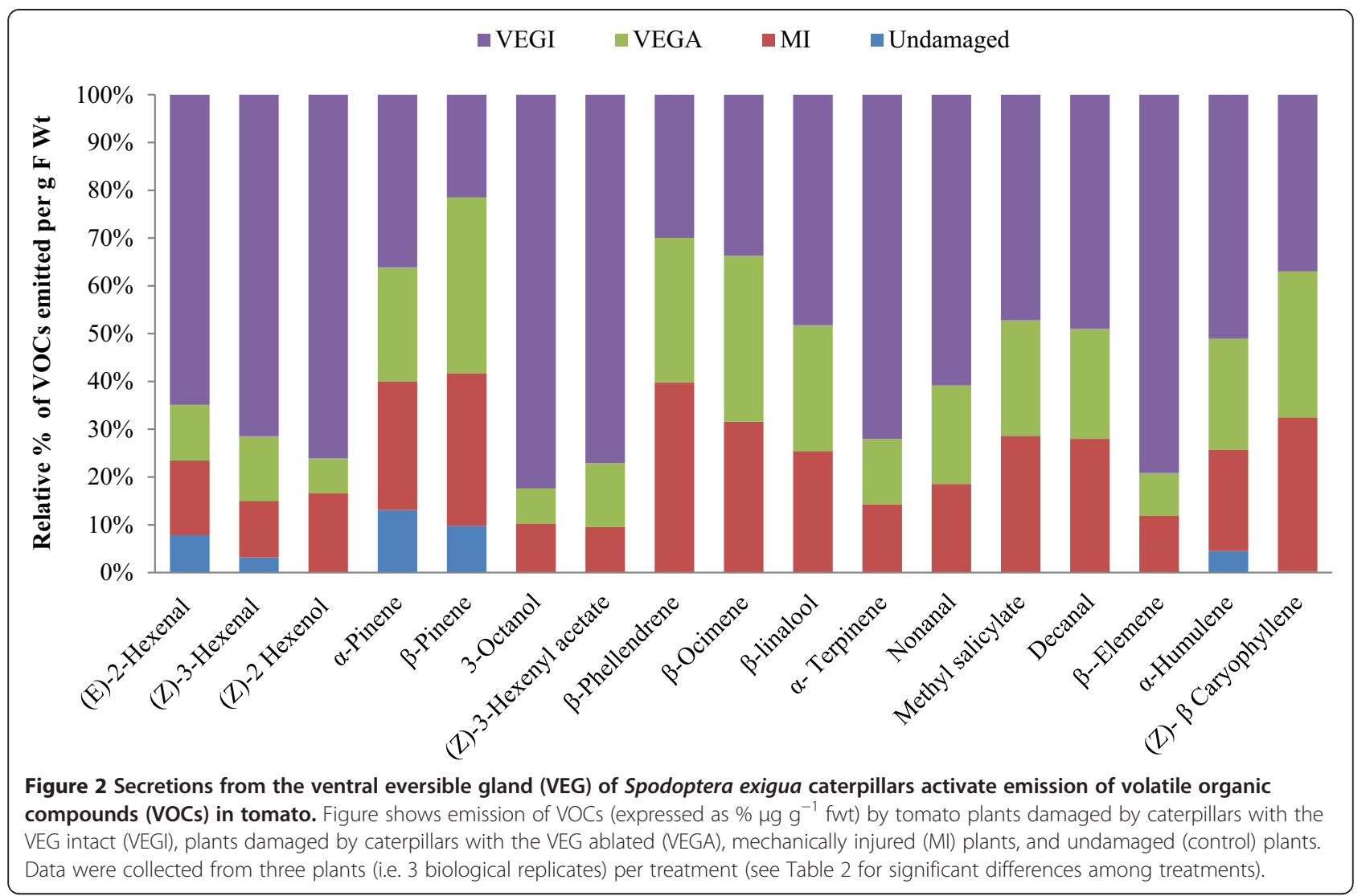

Table 2 Quantitative analysis of emission of volatile organic compounds (VOCs)

\begin{tabular}{|c|c|c|c|c|c|}
\hline VOCs & $\mathrm{KI}$ & VEGI & VEGA & $\mathrm{MI}$ & Undamaged \\
\hline (E)-2-Hexenal & 855 & $14.10(1.94) a$ & $2.53(0.99) \mathrm{b}$ & $3.40(0.93) \mathrm{b}$ & $1.7(0.32) b$ \\
\hline (Z)-3-Hexenal & 865 & 10.27(0.19)a & $1.94(0.33) \mathrm{b}$ & $1.70(0.24) b$ & $0.46(0.03) \mathrm{b}$ \\
\hline (Z)-2 Hexenol & 858 & $13.07(2.53) \mathrm{a}$ & $1.24(0.03) \mathrm{b}$ & $2.86(0.20) b$ & nd \\
\hline a-Pinene & 939 & 15.867(1.40)a & 10.47(0.78)a & $11.82(1.09) \mathrm{a}$ & $5.76(0.01) b$ \\
\hline$\beta$-Pinene & 979 & $1.34(0.54) a$ & $2.29(0.64) a$ & $1.99(0.14) \mathrm{a}$ & $0.61(0.20) b$ \\
\hline 3-Octanol & 991 & $27.39(1.27) a$ & $2.43(0.24) b$ & $3.42(0.60) b$ & nd \\
\hline (Z)-3-Hexenyl acetate & 1002 & 10.09(1.77)a & $1.75(0.16) b$ & $1.25(1.34) \mathrm{b}$ & nd \\
\hline$\beta$-Phellendrene & 1030 & 19.79(1.91)a & $20.01(1.57) a$ & $26.27(1.85) a$ & nd \\
\hline$\beta$-Ocimene & 1040 & $16.58(1.23) \mathrm{a}$ & $17.07(1.31) \mathrm{a}$ & 15.52(0.36)a & nd \\
\hline$\beta$-linalool & 1026 & 19.52(1.70)a & $10.66(0.77) \mathrm{b}$ & $10.30(1.66) \mathrm{b}$ & nd \\
\hline a-Terpinene & 1060 & $16.79(1.03) \mathrm{a}$ & $3.19(0.72) \mathrm{b}$ & $3.33(1.17) \mathrm{b}$ & nd \\
\hline Nonanal & 1101 & $10.82(1.65) \mathrm{a}$ & $3.66(1.74) \mathrm{b}$ & $3.30(0.51) b$ & nd \\
\hline Methyl salicylate & 1190 & 13.14(1.06)a & $6.73(0.32) b$ & $7.97(0.47) b$ & nd \\
\hline Decanal & 1202 & 174.38(1.63)a & $82.27(2.54) b$ & $99.68(4.64) \mathrm{b}$ & nd \\
\hline$\delta$-Elemene & 1338 & $32.85(1.20) a$ & $3.69(0.03) \mathrm{b}$ & 4.96(0.71)b & nd \\
\hline$\beta$ - Elemene & 1319 & 19.89(5.46)a & $9.06(1.22) \mathrm{b}$ & $8.24(0.52) b$ & $1.76(0.21) c$ \\
\hline (Z)- $\beta$-Caryophyllene & 1455 & 106.94(3.61)a & $88.33(10.91) b$ & $93.10(3.13) \mathrm{b}$ & $0.86(0.06) c$ \\
\hline
\end{tabular}

Table shows emission of VOCs ( $\mu \mathrm{g} \mathrm{g}^{-1} \mathrm{fwt}$ ) by tomato plants damaged by caterpillars with the VEG intact (VEGI), plants damaged by caterpillars with the VEG ablated (VEGA), mechanically injured (MI) plants, and undamaged (control) plants.Data were collected from three plants (i.e. 3 biological replicates) per treatment. Means $( \pm$ SEM) within the same row having different letters are significantly different $(P<0.05)$. Kovats retention index $(K I)$ is indicated for each compound. nd $=$ not detected. 
Table 3 Gene expression results

\begin{tabular}{lcccccc}
\hline & VEGI & VEGA & MD + OSVEGI & MD + OSVEGA & MD & Control \\
\hline LOX & $4.47(0.46) \mathrm{b}$ & $0.14(0.15) \mathrm{b}$ & $4.65(1.30) \mathrm{a}$ & $1.13(0.08) \mathrm{b}$ & $0.95(0.12) \mathrm{b}$ & $1.04(0.05) \mathrm{b}$ \\
AOS & $6.01(0.18) \mathrm{b}$ & $1.12(0.21) \mathrm{c}$ & $6.85(1.22) \mathrm{a}$ & $0.96(0.07) \mathrm{c}$ & $0.96(0.16) \mathrm{c}$ & $1.01(0.01) \mathrm{c}$ \\
TPS5 & $4.68(0.39) \mathrm{a}$ & $0.54(0.07) \mathrm{b}$ & $5.31(0.81) \mathrm{a}$ & $1.13(0.17) \mathrm{c}$ & $0.75(0.16) \mathrm{c}$ & $1.08(0.06) \mathrm{c}$ \\
TPS7 & $2.32(0.06) \mathrm{a}$ & $2.19(0.19) \mathrm{a}$ & $1.58(0.91) \mathrm{a}$ & $2.11(0.08) \mathrm{a}$ & $2.02(0.05) \mathrm{a}$ & $1.13(0.16) \mathrm{b}$ \\
TPS12 & $5.57(0.74) \mathrm{a}$ & $0.86(0.23) \mathrm{b}$ & $6.55(0.85) \mathrm{a}$ & $0.90(0.27) \mathrm{b}$ & $0.91(0.26) \mathrm{b}$ & $1.02(0.13) \mathrm{b}$ \\
TPS25 & $2.03(0.28) \mathrm{a}$ & $2.43(0.09) \mathrm{a}$ & $2.21(0.43) \mathrm{a}$ & $2.03(0.10) \mathrm{a}$ & $2.14(0.06) \mathrm{a}$ & $1.13(0.16) \mathrm{b}$
\end{tabular}

Differential expression of genes involved in jasmonic acid (JA) and terpene biosynthesis in tomato plants damaged by caterpillars with the VEG intact (VEGI), plants damaged by caterpillars with the VEG ablated (VEGA), mechanically injured (MI) plants, mechanically injured plants treated with oral secretion (OS) from VEGI caterpillars ( $\mathrm{MI}+$ OSVEGI), mechanically injured plants treated with OS from VEGA caterpillars (MI + OSVEGA), and undamaged (control) plants. qRT-PCR analyses are shown as fold change in expression. Means $( \pm$ SEM) within the same row having different letters are significantly different $(P<0.05)$.

[37], and TPS12 (catalyzes formation of the sesquiterpenes (E)- $\beta$-caryophyllene and $\alpha$-humulene) [38], were significantly higher in plants damaged by VEGI caterpillars and MI + OSVEGI plants compared to the other treatments.

\section{Discussion}

Tomato plants damaged by S. exigua caterpillars with intact ventral eversible gland (VEGI) expressed significantly higher amounts of defense-related enzymes and genes, and headspace VOCs than plants damaged by caterpillars with ablated VEG (VEGA). These results suggest that secretions from the VEG of $S$. exigua caterpillars contain elicitors of late defense signaling in tomato. To our knowledge, this is the first report on the role of caterpillar VEG secretions as an elicitor of late defense signaling in plants. A previous study by Zebelo and Maffei [32] showed that VEG secretions of Spodoptera littoralis caterpillars induced early defense signaling in Arabidopsis thaliana.

The three defense-related enzymes, peroxidase (POD), polyphenol oxidase (PPO), and lipoxigenase (LOX), were expressed in significantly higher amounts in plants damaged by VEGI caterpillars or mechanically injured plants treated with oral secretion (OS) from VEGI caterpillars (MI + OSVEGI) than in plants damaged by VEGA caterpillars, mechanically injured (MI) plants, mechanically injured plants treated with oral secretion (OS) from VEGA caterpillars (MI + OSVEGA), or untreated (control) plants. All three enzymes are components of the octadecanoid signal transduction pathway, which regulates the production of the phytohormone, jasmonic acid (JA) [39-41]. Peroxidases (PODs) are a group of plant defense-related enzymes, which limit plant nutritional quality to insect herbivores through quinone and reactive oxygen species generation with subsequent inhibition of insect digestion of plant material $[41,42]$. Over-expression of PODs can enhance plant resistance to insects [43] and limit plant nutritional quality to insect herbivores [41]. Suzuki et al. [41] reported that herbivory by caterpillars and high POD activity resulted in the up-regulation of several tomato genes including genes encoding proteinase inhibitors.
Polyphenol oxidase (PPO) is an inducible enzyme that is found throughout the plant kingdom and known to have defensive role against herbivores $[40,44]$ and pathogens $[45,46]$. Production of PPO is induced by mechanical injury, methyl jasmonate (MeJa) and herbivory [39]. Similar to our results, Chung et al. [47] reported high PPO levels in tomato plants wounded mechanically and treated with oral secretions (OS) from Colorado potato beetle, Leptinotarsa decemlineata, suggesting that insect OS contain elicitors of PPO activity [47]. Lipoxygenases (LOXs) are another group of anti-oxidative enzymes involved in plant defense against herbivory and pathogens through the octadecanoid pathway [48]. One of the most important functions of LOX in plant defense is the oxidation of linolenic acid in the JA signaling pathway [49]. Allene oxide synthase (AOS) catalyzes the first step of the LOX pathway that leads to JA biosynthesis [49]. In the present study, we observed an early induction of LOX-specific activity within $24 \mathrm{~h}$ of feeding by caterpillars with intact VEG (VEGI). Likewise, the transcript levels of $L O X$ and $A O S$ genes were higher in plants damaged by VEGI caterpillars compared to plants damaged by caterpillars with ablated VEG (VEGA). These results are consistent with previous studies which demonstrate that caterpillar feeding up-regulates the expression of LOX genes in tomato [50].

Our results also showed increased emission of VOCs in tomato plants damaged by VEGI caterpillars compared to plants damaged by VEGA caterpillars or mechanically injured plants. Among the common VOCs induced by herbivory are those that are LOX-derived, such as green leaf volatiles (GLVs), terpenoids and methyl salicylate [51]. Numerous plants emit GLVs and other VOCs as an indirect defense strategy against herbivory, as these volatiles can attract predacious and parasitic natural enemies of herbivores [52-54]. In this study, GLVs and certain monoterpenes were emitted in higher amounts by plants damaged by VEGI caterpillars, suggesting the involvement of the VEG in the induction of plant VOCs. For instance, most GLVs including (E)-2-hexenal, (Z)-3-hexenal, $(Z)$-2-hexenol and (Z)-3-hexenyl acetate were detected in higher amounts in 
plants damaged by VEGI caterpillars compared to plants damaged by VEGA caterpillars. Interestingly, many of these GLVs are used as host location cues by caterpillar parasitoids [55], suggesting that VEG secretions may impact tritrophic interactions. GLVs have also been reported to play a role in plant-plant interactions [56].

Another highly diverse group of plant compounds are the terpenoids, which are synthesized by a group of enzymes called terpene synthases (TPS) to produce mono-, sesqui- and diterpenes [51]. Terpenes are more costly to synthesize per gram than most other primary and secondary plant compounds [57]. Studies have shown that a single mechanical plant tissue injury event may not elicit induced defense related volatile organic compounds (VOCs) $[58,59]$. However, application of OS to mechanically wounded site could elicit the release of inducible volatile compounds and thereby mimic herbivory $[58,59]$. In the present study, we observed significantly higher emission of the monoterpenes, $\beta$-linalool and $\gamma$-terpinene, in plants damaged by VEGI caterpillars compared to those damaged by VEGA caterpillars. However, there were no significant differences recorded among the treatments in the emission of other monoterpenes such as $\alpha$-pinene, $\beta$-phellendrene, $\beta$-pinene and $\beta$-ocimene, suggesting that not all VOCs are inducible by VEG secretions.

Like monoterpenes, sesquiterpenes are phytoalexins which play a pivotal role in direct and indirect defenses against herbivores [60]. In the present study, several sesquiterpenes (i.e. $(E)-\beta$-caryophyllene, $\alpha$-humulene and $\beta$ elemene), some fatty acids (3- octanol and nonanal) and an organic ester (methyl salicylate) were emitted in significantly higher amounts by plants damaged by VEGI caterpillars compared to plants damaged by VEGA caterpillars.

Results from gene expression studies showed that most terpene synthase genes (i.e. TPS7 which encodes the monoterpene, $\beta$-Ocimene and TPS12 which encodes the sesquiterpenes, $(E)-\beta$-caryophyllene and $\alpha$-humulene) and the genes involved in the biosynthesis of GLVs and jasmonic acid (i.e. $L O X$ and $A O S$ ) were up-regulated in plants damaged by VEGI caterpillars as well as in mechanically injured plants treated with oral secretion from VEGI caterpillars (MI + OSVEGI). However, the transcript levels of these genes were not up-regulated in plants damaged by VEGA caterpillars, mechanically injured plants treated with oral secretion from VEGA caterpillars $(\mathrm{MI}+$ OSVEGA), or mechanically injured (MI) plants. These results suggest that an intact VEG in S. exigua caterpillars is crucial for eliciting late defense signaling via the expression of defense-related genes. These findings are in agreement with those of Bricchi et al. [3] which showed that mechanical injury alone failed to increase the transcript levels of terpene synthase and JA biosynthesis genes in Arabidobsis thaliana, but mechanical injury treated with Spodoptera littoralis oral secretion activated the genes.
In a recent review of the role of caterpillar secretions on induced plant defenses, Felton [61] suggested that the VEG may play an important role in secretion during feeding by caterpillars in the family Noctuidae. The structure and proximity of the VEG to the caterpillar mouthparts lend credence to this proposal. When a caterpillar feeds on a plant material the VEG is distended from its eversible position on the ventral surface of the caterpillar thorax and reaches the injured plant surface $[32,61]$. Furthermore, because the tip of the everted VEG can reach the mandibles during feeding [35], the VEG secretions are usually deposited onto the food substrate with the OS [32]. Our results confirm that the VEG secretions, which are deposited along with oral secretions or regurgitate onto plants during caterpillar feeding can induce late defense signaling in tomato. Further studies are needed to identify the bioactive components of the VEG secretions that trigger plant defense signaling.

\section{Conclusion}

The VEG was first reported in 1745 [62], but very little is known about its role in plant-insect interactions. Our current results suggest that the VEG of S. exigua contain elicitors of late plant defense signaling which may trigger defense-related enzymatic activity, regulate expression of terpene synthase genes and other defense-related genes, and induce plant VOCs, with potential ramifications for plant-insect and tritrophic interactions. Studies are underway in our lab to investigate whether the VEG secretion alone or in combination with other labial gland secretions and gut regurgitates trigger plant responses against insect herbivory. Further studies are needed to comprehend the complexity of plant signaling networks and the role of insect oral secretions in mediating plantinsect and trititrophic interactions.

\section{Methods}

\section{Plant and animal material}

Tomato plants (Solanum lycopersicon Mill. cv Microtom) were grown from seeds in plastic pots with sterilized sunshine mix soil at $23^{\circ} \mathrm{C}$ and $60 \%$ relative humidity using daylight fluorescent tubes $\left(270 \mu \mathrm{mol} \mathrm{m} \mathrm{m}^{-2} \mathrm{~s}^{-1}\right)$ with a light phase of $16 \mathrm{~h}$. Six weeks old non-flowering potted tomato plants were used for the experiments. Spodoptera exigua eggs purchased from Benzon Research (Carlisle, PA) were used to start laboratory colonies at Auburn University (Auburn, AL). Caterpillars were fed a laboratory-prepared pinto bean diet and maintained at $25 \pm 1^{\circ} \mathrm{C}, 75 \pm 5 \%$ relative humidity, and 14:10-h (L/D) photoperiod.

\section{VEG ablation and oral secretion collection}

VEG ablation (VEGA) was done as previously described in Zebelo and Maffei [32] with little modification. Thirdinstar larvae were chilled on ice until they became 
inactive. Using stainless steel pins each caterpillar was held in a styrofoam comb by bending the pins against its body. The styrofoam with caterpillar was placed under olympus stereomicroscope (Tokyo, Japan) set at magnification of $250 x$. The caterpillar head was gently pushed backwards with cotton ear buds to evert the VEG, and a stainless steel pin was heated with a Bunsen flame until it turns glowing red and then brought close to the everted VEG. The VEG was turned to a whitish-milky color after heat treatment (Figure 3A), and after ablation VEGs were not regenerated after molting. VEGA larvae were allowed to feed for $24 \mathrm{~h}$ on tomato leaves. Control larvae (i.e. larvae with VEG intact, VEGI) were chilled and placed in a styrofoam comb, elicited to evert the VEG, but not treated with the heated pin (Figure 3B). VEGI larvae were also allowed to feed for $24 \mathrm{~h}$ on tomato leaves. Third-instar VEGA and VEGI caterpillars were allowed to molt to the fourth and fifth instars. This allowed them to acclimate to the host plant, recover from the ablation and resume feeding prior to the tests. To compare the level of damage caused by VEGA and VEGI caterpillars, Leaves were excised from tomato plants and placed in $8 \mathrm{~cm}$ diameter Petridish carpeted with moist white paper towel. The excised leaves were plugged at the petiole with wet cotton balls to prevent desiccation. VEGA and VEGI caterpillars were allowed to feed on excised leaves (one larva per leaf). The portion of the leaf fed upon by the larva was quantified after one day by scanning the leaf. The scanned images were imported into Image J software (Image); http://rsbweb. nih.gov/ij/) to measure the amount of leaf consumed.
Oral secretion was collected from VEGI and VEGA caterpillars as previously described in Zebelo and Maffei [32]. The OS was diluted in $5 \mathrm{mM} 2$-(N-morpholino) ethanesulfonic acid (Mes- $\mathrm{NaOH})(\mathrm{pH}$ 6.0) buffer at the rate $1: 5$ and $5 \mu \mathrm{l}$ was applied at the site of mechanical injury (MI) in tomato leaves with a micro-syringe. The ratio of oral secretion to Mes- $\mathrm{NaOH}$ buffer and the amount of OS solution added to mechanical injured (MI) tomato plants were as reported in previous studies [3,6,10,11,32]. Moreover, previous studies have shown that Mes- $\mathrm{NaOH}$ buffer alone failed to trigger plant defense signaling $[3,6,10,11,32]$.

\section{Live/Dead VEG assay}

After acclimation and recovery from ablation, representative VEGI and VEGA caterpillars from the above treatments were chilled again on ice until flaccid and placed in a styrofoam comb. Using stainless steel pins each caterpillar was held in a styrofoam comb by bending the pins against its body. The caterpillar head was pushed backwards to evert the VEG and a fine-point forcep was used to remove the VEG, free of oral secretions or excess hemolymph and directly placed in microscopic concave well slides (Microscope world, Carlsbad CA, USA). The LIVE/DEAD viability/cytotoxicity assay kit (Biotium Hatward, CA, USA) was used to confirm VEG ablation. Two-color fluorescence cell viability assay was done with an Olympus fluorescence microscope (BX61, Tokyo, Japan) set at magnification $40 \mathrm{X}$.

Ethidium homodimer-1 (EthD-III, which is a component of the assay kit) enters cells with damaged membranes and
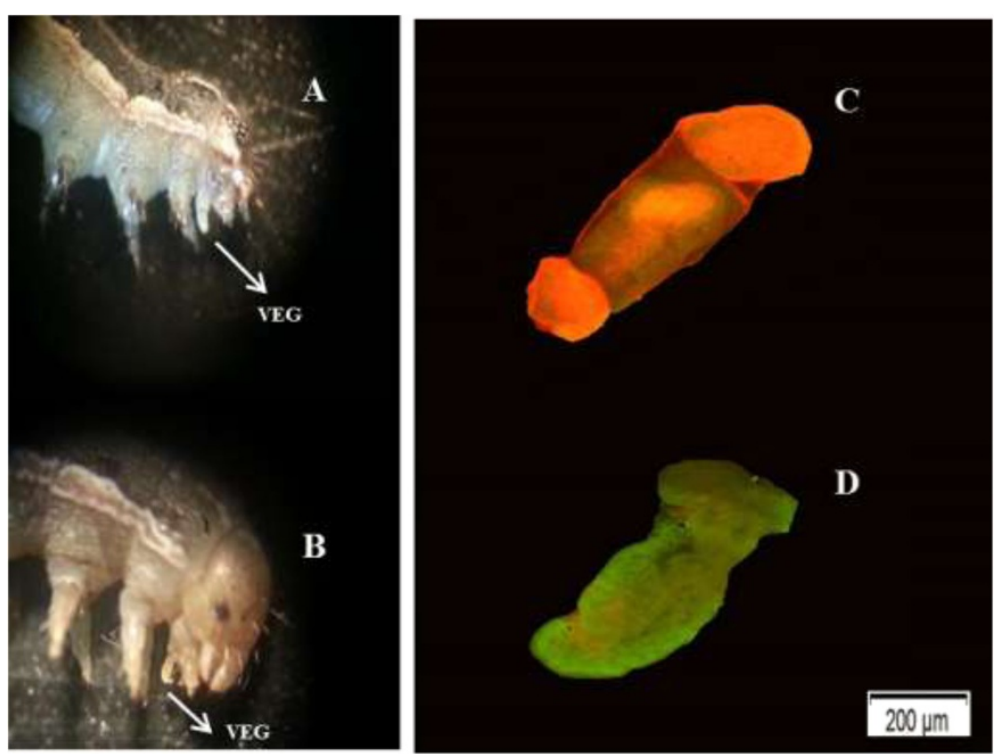

Figure 3 Micrographs of the ventral eversible gland (VEG) of Spodoptera exigua caterpillar. VEG treated with heat (A), Intact VEG - not treated with heat (B), Dead VEG due to heat treatment (ethidium homodimer-1 is well retained in dead VEG cells, producing a bright red fluorescence (C), and Intact VEG polyanionic dye calcein is well retained in live VEG cells, producing an intense uniform green fluorescence (D). Magnification = 250X. 
undergoes a 40-fold enhancement of fluorescence upon binding to nucleic acids, thereby producing a bright red fluorescence in dead cells (ex/em $\sim 495 \mathrm{~nm}-635 \mathrm{~nm}$ ) (Figure 3C). Live cells were distinguished by the presence of ubiquitous intracellular esterase activity, determined by the enzymatic conversion of the virtually non-fluorescent cell-permeating calcein acetoxymethyl (AM) to the intensely-fluorescent calcein. The polyanionic dye calcein is well retained within live cells, producing an intense uniform green fluorescence in live cells (ex/em $\sim 495 \mathrm{~nm} / \sim 515 \mathrm{~nm}$ ) (Figure 3D). The VEG tissue labeling was done according to the manufacturer's recommendations.

\section{Enzyme assays}

We quantified the activity of three enzymes involved in plant defense in response to insect herbivores: peroxidase (POD), polyphenol oxidase (PPO) and lipoxygenase (LOX). Leaf samples were collected from tomato plants damaged by VEGI caterpillars, VEGA caterpillars, mechanically injured (MI) plants, mechanically injured plants treated with OS from VEGI caterpillars (MI + OSVEGI), mechanically injured plants treated with OS from VEGA caterpillars (MI + OSVEGA), and undamaged (control) plants, at $0,24,48$ and $72 \mathrm{~h}$ after caterpillar feeding. Ten leaves per plant were grounded in liquid nitrogen and $0.2 \mathrm{~g}$ of grounded leaves from each sample was homogenized in $2 \mathrm{ml}$ ice-cold $0.05 \mathrm{M}$ phosphate buffer ( $\mathrm{pH} 7.2$ for POD, $\mathrm{pH} 7.8$ for PPO) containing $1 \%(\mathrm{w} / \mathrm{v})$ polyvinylpyrrolidone (PVP). The homogenate was centrifuged at $12,000 \mathrm{~g}$ for $45 \mathrm{~min}$ at $4^{\circ} \mathrm{C}$. The supernatant was collected and used for POD and PPO assays. POD activity was determined as described in [63]. PPO activity was assayed with $0.05 \mathrm{M}$ catechol as a substrate by a spectrophotometric procedure [64].
LOX activity was measured as conjugated diene formation [65]. Leaves were ground in liquid nitrogen and $0.2 \mathrm{~g}$ of grounded leaves from each sample was homogenized with $1 \mathrm{ml}$ ice-cold $0.5 \mathrm{M}$ Tris- $\mathrm{HCl}$ buffer ( $\mathrm{pH}$ 7.6) and centrifuged at $12,000 \mathrm{~g}$ for $45 \mathrm{~min}$ at $4^{\circ} \mathrm{C}$. The supernatant was kept at $4^{\circ} \mathrm{C}$ until used. The substrate contained $1.6 \mathrm{mM}$ linoleic acid and $0.5 \%(\mathrm{v} / \mathrm{v})$ Tween 20 in $0.1 \mathrm{M}$ phosphate buffer ( $\mathrm{pH}$ 7.6). The reaction was initiated by the addition of $0.2 \mathrm{ml}$ of the supernatant in $4.8 \mathrm{ml}$ of the substrate. Diene formation was measured as increase of absorbance at $234 \mathrm{~nm}$.

Enzymatic activity was calculated by employing the linear regression equation of respective substrate production over time, on the basis of an extinction coefficient estimated with an authentic standard. The catalytic activity of the enzyme was calculated in katal (Kat), which is defined as the amount of enzyme that catalyzes the formation of $1 \mathrm{~mol}$ of substrate $\mathrm{s}^{-1}$ under the above assay conditions. Protein concentration was quantified by the method of Bradford [66] using bovine serum albumin as the standard. The data were analyzed using one-way ANOVA followed by the Tukey-Kramer HSD multiple comparison test at a significance level of $P<0.05$.

\section{Collection of VOCs from tomato plants damaged by VEGI versus VEGA caterpillars}

To determine the role of the VEG on VOC emission in tomato, headspace volatiles were collected from plants damaged by VEGI caterpillars, VEGA caterpillars, mechanically injured (MI) plants, and undamaged (control) plants. Fifteen $3^{\text {rd }}$ instar S. exigua caterpillars (VEGI or VEGA) were allowed to feed on a potted tomato plant for $24 \mathrm{~h}$. Feeding by these caterpillars for $6 \mathrm{~h}$ resulted in $\sim 25-35 \%$ leaf area damage, which is similar to the mechanical injury simulation with pattern wheel, as

Table 4 Primers used for RT-qPCR

\begin{tabular}{|c|c|c|c|c|}
\hline Genes & Direction & Primer sequences $\left(5^{\prime}-3^{\prime}\right)$ & GenBank (AN) & References \\
\hline \multirow[t]{2}{*}{$\overline{A O S}$} & Forward & GGGTGAAATCCTATTCGGGT & AF230371 & {$[68]$} \\
\hline & Reverse & CGCACTGTTTATTCCCCACT & & \\
\hline \multirow[t]{2}{*}{ LOX2 } & Forward & TGCAACACGCACCATTTATT & U37840 & {$[50]$} \\
\hline & Reverse & GTGACAACACGTTTGGATCG & & \\
\hline \multirow[t]{2}{*}{ TPS5 } & Forward & CTATTTCCACCACAAGGCGT & AY840091 & {$[37]$} \\
\hline & Reverse & TTCATCATGTGATCCCTCCA & & \\
\hline \multirow[t]{2}{*}{ TPS12 } & Forward & GCCCAATGGTTAAACAATGATAATC & JN412092 & {$[37]$} \\
\hline & Reverse & ATATAACGTGTTAATCACGCGTGTG & & \\
\hline \multirow[t]{2}{*}{ TPS25 } & Forward & GTGGGTCAACTTCTGTAAAGCTTTAC & JN412085 & {$[37]$} \\
\hline & Reverse & TGATTAACAATTTITTCTGTGATGTT & & \\
\hline \multirow[t]{2}{*}{ TPS7 } & Forward & CAAGGAGTATGTTAATGTCAGG & JN412082 & {$[37]$} \\
\hline & Reverse & GCTTCATATAAGTTCAATATTCC & & \\
\hline
\end{tabular}


previously described in [13]. The pot with the potting soil was wrapped with aluminum foil to minimize evaporation of water and volatiles from the soil and placed in a volatile collection chamber consisting of a $5 \mathrm{~L}$ glass jar. A purified (using activated charcoal) air stream of $350 \mathrm{ml} / \mathrm{min}$ was passed through the jar at room temperature for $24 \mathrm{~h}$ and plants were illuminated with fluorescent light bulbs generating $50 \mu \mathrm{mol} \mathrm{m} \mathrm{m}^{-2}$ $\mathrm{s}^{-1}$ with a photoperiod of $16 \mathrm{~h}$. Headspace volatiles were collected using a trap containing $50 \mathrm{mg}$ of SuperQ (Alltech Associates, Deerfield, IL) and eluted with $300 \mu \mathrm{l}$ of methylene chloride. The resulting extracts $(300 \mu \mathrm{l})$ were stored in a freezer $\left(\right.$ at $\left.-20^{\circ} \mathrm{C}\right)$ until use. Another container with potting soil without plant or caterpillars was used to check for miscellaneous impurities and breakthrough of the trap during sampling. One microliter of each headspace volatile extract was analyzed by gas-chromatography (Agilent Technologies, mod. 7890A) coupled with mass spectrometry (Agilent technologies, mod. 5975C), as described in [13]. Compounds were identified by comparison of their mass spectra and retention indices (Kováts index) with those of reference substances and by comparison with the NIST mass spectral search software v 2.0 using the NIST 05 library (National Institute of Standards and Technology, Gaithersburg, MD, USA). External calibration curves were made with standard solutions of $(E)$-2-hexenal, $\alpha$-pinene and $(E)$ - $\beta$-caryophyllene for quantitative measurements, as previously described in [13]. The data were analyzed by using oneway ANOVA followed by the Tukey-Kramer HSD multiple comparison test at a significance level of $P<0.05$.

\section{Total RNA isolation and CDNA synthesis}

Leaf samples were collected from tomato plants damaged by VEGI caterpillars, VEGA caterpillars, mechanically injured (MI) plants, mechanical injured plants treated with OS from VEGI caterpillars (MI + OSVEGI), mechanical injured plants treated with OS from VEGA caterpillars (MI + OSVEGA), and undamaged (control plants), after $12 \mathrm{~h}$ of caterpillars feeding. Leaf samples were immediately frozen in liquid nitrogen and kept at $-80^{\circ} \mathrm{C}$. Frozen samples were ground to a fine powder in liquid nitrogen with a pestle and mortar. Total RNA was extracted from $100 \mathrm{mg}$ of each leaf sample using Spectrum ${ }^{\mathrm{Tw}}$ plant total RNA kit (Sigma Aldrich, St. Louis, MO, USA), according to the manufacturer's instructions. RNA concentration and purity were determined using a NanoDrop ${ }^{\mathrm{Tm}}$ Spectrophotometer ND-2000 (Thermo Scientific, Wilmington, DE, USA), and the integrity of RNA was also assessed by $1 \%$ agarose gel electrophoresis and ethidium bromide staining. The absence of contaminant DNA in the RNA samples was verified by PCR using specific primers of a known gene and gel electrophoresis analysis. No fragments of genomic DNA were identified in all samples tested in this work.
First strand cDNA was synthesized from 200 ng RNA using a Goscrpit ${ }^{\mathrm{Tm}}$ Reverse Transcription System Kit (Promega, Madison, WI, USA) according to the manufacturer's instructions.

\section{Real-time PCR}

The transcript levels of genes that are involved in tomato defense signaling pathway, such as lipoxygenase (LOX2), allene oxide synthase (AOS), and four terpene synthase (TPS) genes, were measured by quantitative RT-PCR (see list of primers used in Table 4). Quantitative real-time PCR (qrtPCR) was carried out on an ABI 7500 Real Time PCR System (Life Technologies, Carlsbad, CA, USA) with a 96 well rotor. The amplification reactions were performed with $25 \mu \mathrm{l}$ of mixture consisting of $12.5 \mu \mathrm{l}$ of PerfeCTA ${ }^{\circ}$ SYBR $^{\circ}$ Green Fastmix ${ }^{\circ}$ LOW ROX qPCR Master Mix (Quanta Biosciences, Inc, Gaithersburg, MD, USA), $0.5 \mu \mathrm{l}$ of cDNA and $100 \mathrm{nM}$ primers (Integrated DNA Technologies, Coralville, IA, USA). Relative RNA levels were calibrated and normalized with the level of two housekeeping genes: Actin and $18 S$ ribosomal mRNA. PCR conditions were determined by comparing threshold values in a dilution series of the RT product, followed by non-template control for each primer pair. Relative expression levels of genes were calculated by using the Pfaffl method [67]. A suitable melt curve analysis was also performed. The data were analyzed by using one-way ANOVA followed by the TukeyKramer HSD multiple comparison test at a significance level of $P<0.05$.

\section{Abbreviations}

VEG: Ventral eversible gland; VOCs: Volatile organic compounds; ROS: Reactive oxygen species; MI: Mechanical injury; VEGI: VEG Intact; VEGA: VEG ablated; OS: Oral secretion; AOS: Allene oxide synthase; LOX: Lipoxygenase; TPS: Terpene synthases; MI + OSVEGI: Mechanically injured plants treated with OS from VEGI caterpillars; MI + OSVEGA: Mechanically injured plants treated with OS from VEGA caterpillars.

\section{Competing interests}

The authors declare that they have no competing interests.

\section{Authors' contributions}

$\mathrm{HF}$ and $\mathrm{SZ}$ designed the study. SZ, JP and JD performed the research. SZ analyzed the data. HF and SZ wrote the paper. All authors read and approved the final manuscript.

\section{Acknowledgements}

We thank Heather Leyva for assisting with micrographic images.

Received: 22 January 2014 Accepted: 12 May 2014

Published: 20 May 2014

\section{References}

1. Alborn HT, Turlings TCJ, Jones TH, Stenhagen G, Loughrin JH, Tumlinson JH: An elicitor of plant volatiles from beet armyworm oral secretion. Science 1997, 276(5314):945-949.

2. Arimura Gl, Ozawa $R$, Maffei ME: Recent advances in plant early signaling in response to Herbivory. Int J Mol Sci 2011, 12(6):3723-3739.

3. Bricchi I, Occhipinti A, Bertea CM, Zebelo SA, Brillada C, Verrillo F, De Castro C, Molinaro A, Faulkner C, Maule AJ, Maffei ME: Separation of early and late 
responses to herbivory in Arabidopsis by changing plasmodesmal function. Plant J 2013, 73(1):14-25.

4. Hilker M, Meiners T: How do plants "notice" attack by herbivorous arthropods? Biol Rev 2010, 85(2):267-280.

5. Musser RO, Hum-Musser SM, Eichenseer H, Peiffer M, Ervin G, Murphy JB, Felton GW: Herbivory: caterpillar saliva beats plant defences - a new weapon emerges in the evolutionary arms race between plants and herbivores. Nature 2002, 416(6881):599-600.

6. Maffei M, Bossi S, Spiteller D, Mithofer A, Boland W: Effects of feeding Spodoptera littoralis on lima bean leaves. I. membrane potentials, intracellular calcium variations, oral secretions, and regurgitate components. Plant Physiol 2004, 134(4):1752-1762

7. Maffei ME, Mithofer A, Boland W: Insects feeding on plants: rapid signals and responses preceding the induction of phytochemical release. Phytochemistry 2007, 68(22-24):2946-2959.

8. Zebelo SA, Maffei M: Signal Transduction in Plant-Insect Interactions: From Membrane Potential Variations to Metabolomics. In Plant Electrophysiology. Edited by Volkov AG. Berlin Heidelberg: Springer; 2012:143-172

9. Arimura G, Maffei ME: Calcium and secondary CPK signaling in plants in response to herbivore attack. Biochem Bioph Res Co 2010, 400(4):455-460.

10. Bricchi I, Leitner M, Foti M, Mithofer A, Boland W, Maffei ME: Robotic mechanical wounding (MecWorm) versus herbivore-induced responses: early signaling and volatile emission in Lima bean (Phaseolus lunatus L.). Planta 2010, 232(3):719-729.

11. Maffei ME, Mithofer A, Arimura GI, Uchtenhagen H, Bossi S, Bertea CM, Cucuzza LS, Novero M, Volpe V, Quadro S, Boland W: Effects of feeding Spodoptera littoralis on lima bean leaves. III. Membrane depolarization and involvement of hydrogen peroxide. Plant Physiol 2006, 140(3):1022-1035.

12. Occhipinti A, Zebelo SA, Capuzzo A, Maffei M, Gnavi G: Chrysolina herbacea modulates jasmonic acid, cis-(+)-12-oxophytodienoic acid, (3R,7S)-jasmonoyl---isoleucine, and salicylic acid of local and systemic leaves in the host plant Mentha aquatica. J Plant Interact 2011 6(2-3):99-101.

13. Zebelo SA, Bertea CM, Bossi S, Occhipinti A, Gnavi G, Maffei ME: Chrysolina herbacea modulates terpenoid biosynthesis of mentha aquatica L. Plos One 2011, 6(3).

14. Pare PW, Tumlinson JH: Plant volatiles as a defense against insect herbivores. Plant Physio/ 1999, 121(2):325-331.

15. Mattiacci L, Dicke M, Posthumus MA: Beta-Glucosidase - an Elicitor of Herbivore-Induced plant odor that attracts host-searching parasitic wasps. Proc Natl Acad Sci U S A 1995, 92(6):2036-2040.

16. Howe GA, Jander G: Plant immunity to insect herbivores. Annu Rev Plant Biol 2008, 59:41-66.

17. Karban R: The ecology and evolution of induced resistance against herbivores. Funct Ecol 2011, 25(2):339-347.

18. Maffei ME, Mithofer A, Boland W: Before gene expression: early events in plant-insect interaction. Trends Plant Sci 2007, 12(7):310-316

19. Felton G: Caterpillar Secretions and Induced Plant Responses. In Induced Plant Resistance to Herbivory. Edited by Schaller A. Netherlands: Springer; 2008:369-387.

20. Lawrence SD, Novak NG: Maize genes induced by herbivory and volicitin J Chem Ecol 2004, 30(12):2543-2557.

21. Major IT, Constabel CP: Molecular analysis of poplar defense against herbivory: comparison of wound- and insect elicitor-induced gene expression. New Phytol 2006, 172(4):617-635.

22. Reymond P, Bodenhausen N, Van Poecke RMP, Krishnamurthy V, Dicke M, Farmer EE: A conserved transcript pattern in response to a specialist and a generalist herbivore. Plant Cell 2004, 16(11):3132-3147

23. Reymond $\mathrm{P}$, Weber H, Damond M, Farmer EE: Differential gene expression in response to mechanical wounding and insect feeding in Arabidopsis. Plant Cell 2000, 12(5):707-719.

24. Roda A, Halitschke R, Steppuhn A, Baldwin IT: Individual variability in herbivore-specific elicitors from the plant's perspective. Mol Ecol 2004 13(8):2421-2433.

25. Schmelz EA, Carroll MJ, LeClere S, Phipps SM, Meredith J, Chourey PS, Alborn HT, Teal PEA: Fragments of ATP synthase mediate plant perception of insect attack. Proc Natl Acad Sci U S A 2006, 103(23):8894-8899.

26. Halitschke R, Gase K, Hui DQ, Schmidt DD, Baldwin IT: Molecula interactions between the specialist herbivore Manduca sexta (Lepidoptera, Sphingidae) and its natural host Nicotiana attenuata. VI microarray analysis reveals that most herbivore-specific transcriptional changes are mediated by fatty acid-amino acid conjugates. Plant Physiol 2003, 131(4):1894-1902.

27. Consales F, Schweizer F, Erb M, Gouhier-Darimont C, Bodenhausen N, Bruessow F, Sobhy I, Reymond P: Insect oral secretions suppress woundinduced responses in Arabidopsis. J Exp Bot 2012, 63(2):727-737.

28. Halitschke R, Schittko U, Pohnert G, Boland W, Baldwin IT: Molecular interactions between the specialist herbivore Manduca sexta (Lepidoptera, Sphingidae) and its natural host Nicotiana attenuata. III fatty acid-amino acid conjugates in herbivore oral secretions are necessary and sufficient for herbivore-specific plant responses. Plant Physiol 2001, 125(2):711-717.

29. Pohnert G, Jung V, Haukioja E, Lempa K, Boland W: New fatty acid amides from regurgitant of lepidopteran (Noctuidae, Geometridae) caterpillars. Tetrahedron 1999, 55(37):11275-11280.

30. Alborn HT, Hansen TV, Jones TH, Bennett DC, Tumlinson JH, Schmelz EA, Teal PEA: Disulfooxy fatty acids from the American bird grasshopper Schistocerca americana, elicitors of plant volatiles. Proc Natl Acad SC U S A 2007, 104(32):12976-12981.

31. Musser RO, Farmer E, Peiffer M, Williams SA, Felton GW: Ablation of caterpillar labial salivary glands: technique for determining the role of saliva in insect-plant interactions. J Chem Ecol 2006, 32(5):981-992.

32. Zebelo SA, Maffei ME: The ventral eversible gland (VEG) of Spodoptera littoralis triggers early responses to herbivory in Arabidopsis thaliana. Arthropod-Plant Inte 2012, 6(4):543-551.

33. Yoshinaga N, Morigaki N, Matsuda F, Nishida R, Mori N: In vitro biosynthesis of volicitin in Spodoptera litura (vol 35, pg 175, 2005). Insect Biochem Molec 2005, 35(8):945-945.

34. Marti OG, Hamm JJ: Discharge of Hemolymph from the Ventral Eversible Gland of Ascovirus-Infected Fall Armyworm Larvae, Spodoptera-Frugiperda (Lepidoptera, Noctuidae). J Invertebr Pathol 1987, 49(1):127-129.

35. Marti OG, Rogers CE: Anatomy of the Ventral Eversible Gland of Fall Armyworm, Spodoptera-Frugiperda (Lepidoptera, Noctuidae). Larvae Ann Entomol Soc Am 1988, 81(2):308-317.

36. Dickens J, Smith J, Light D: Green leaf volatiles enhance sex attractant pheromone of the tobacco budworm, Heliothis virescens (Lep.: Noctuidae). Chemoecology 1993, 4(3-4):175-177.

37. Bernays EA, Chapman RF: Plant secondary compounds and grasshoppers: beyond plant defenses. J Chem Ecol 2000, 26(8):1773-1794.

38. Falara V, Akhtar TA, Nguyen TTH, Spyropoulou EA, Bleeker PM, Schauvinhold I, Matsuba Y, Bonini ME, Schilmiller AL, Last RL, Schuurink RC, Pichersky E: The Tomato Terpene Synthase Gene Family. Plant Physiol 2011, 157(2):770-789.

39. Constabel CP, Bergey DR, Ryan CA: Systemin activates synthesis of wound-inducible tomato leaf Polyphenol oxidase Via the Octadecanoid defense signaling pathway. Proc Natl Acad Sci U S A 1995, 92(2):407-411.

40. Felton GW, Donato K, Delvecchio RJ, Duffey SS: Activation of plant foliar oxidases by insect feeding reduces nutritive quality of foliage for Noctuid Herbivores. J Chem Ecol 1989, 15(12):2667-2694.

41. Johnson MTJ, Smith SD, Rausher MD: Plant sex and the evolution of plant defenses against herbivores. Proc Natl Acad Sci U S A 2009. 106(43):18079-18084.

42. Dowd PF: Relative inhibition of insect phenoloxidase by cyclic fungal metabolites from insect and plant pathogens. Nat Toxins 1999, 7(6):337-341.

43. Dowd PF, Johnson ET, Pinkerton TS: Identification and properties of insect resistance-associated maize anionic peroxidases. Phytochemistry 2010, 71(11-12):1289-1297.

44. Felton GW, Donato KK, Broadway RM, Duffey SS: Impact of oxidized plant phenolics on the nutritional quality of dietary-protein to a Noctuid Herbivore, Spodoptera-Exigua. J Insect Physiol 1992, 38(4):277-285.

45. Kiraly Z, Farkas GL: Relation between phenol metabolism and stem rust resistance in wheat. Phytopathology 1962, 52(7):657.

46. Kosuge T: Role of phenolics in host response to infection. Annu Rev Phytopathol 1969, 7:195.

47. Chung SH, Felton GW: Specificity of induced resistance in tomato against specialist lepidopteran and coleopteran species. J Chem Ecol 2011, 37(4):378-386.

48. Bruinsma M, Posthumus MA, Mumm R, Mueller MJ, van Loon JJA, Dicke M: Jasmonic acid-induced volatiles of Brassica oleracea attract parasitoids: effects of time and dose, and comparison with induction by herbivores. J Exp Bot 2009, 60(9):2575-2587.

49. Hamberg M, Gardner HW: Oxylipin pathway to Jasmonates - biochemistry and biological significance. Biochim Biophys Acta 1992, 1165(1):1-18. 
50. Heitz T, Bergey DR, Ryan CA: A gene encoding a chloroplast-targeted lipoxygenase in tomato leaves is transiently induced by wounding, systemin, and methyl jasmonate. Plant Physiol 1997, 114(3):1085-1093.

51. Kessler A, Baldwin IT: Plant responses to insect herbivory: the emerging molecular analysis. Annu Rev Plant Biol 2002, 53:299-328.

52. Ngumbi E, Chen L, Fadamiro HY: Comparative GC-EAD responses of A specialist (Microplitis croceipes) and a generalist (Cotesia marginiventris) Parasitoid to cotton volatiles induced by two caterpillar species. $J$ Chem Ecol 2009, 35(9):1009-1020.

53. Chen L, Fadamiro HY: Differential electroantennogram response of females and males of two parasitoid species to host-related green leaf volatiles and inducible compounds. B Entomol Res 2007, 97(5):515-522.

54. Penaflor MFGV, Erb M, Miranda LA, Werneburg AG, Bento JMS: Herbivore-Induced plant volatiles can serve as host location cues for a generalist and a specialist egg Parasitoid. J Chem Ecol 2011, 37(12):1304-1313.

55. Pinto DM, Nerg AM, Holopainen JK: The role of ozone-reactive compounds, terpenes, and green leaf volatiles (GLVs), in the orientation of Cotesia plutellae. J Chem Ecol 2007, 33(12):2218-2228.

56. Zebelo SA, Matsui K, Ozawa R, Maffei ME: Plasma membrane potential depolarization and cytosolic calcium flux are early events involved in tomato (Solanum lycopersicon) plant-to-plant communication. Plant Sci 2012, 196:93-100.

57. Gershenzon J: Metabolic costs of Terpenoid accumulation in higherplants. J Chem Ecol 1994, 20(6):1281-1328.

58. Halitschke R, Kessler A, Kahl J, Lorenz A, Baldwin IT: Ecophysiological comparison of direct and indirect defenses in Nicotiana attenuata. Oecologia 2000, 124(3):408-417.

59. Gill R, Gupta A, Taggar G, Taggar M: Review article: role of oxidative enzymes in plant defenses against insect herbivory. Acta Phytopathologica et Entomologica Hung 2010, 45(2):277-290

60. Cheng AX, Lou YG, Mao YB, Lu S, Wang L, Chen XY: Plant terpenoids: biosynthesis and ecological functions. J Integr Plant Biol 2007, 49(2):179-186

61. Bhonwong A, Stout MJ, Attajarusit J, Tantasawat P: Defensive role of tomato Polyphenol oxidases against Cotton Bollworm (Helicoverpa armigera) and Beet Armyworm (Spodoptera exigua). J Chem Ecol 2009, 35(1):28-38.

62. 113-127 LO: The prothoracic gland of Dicranura vinula and other notes. Trans R Entomol Soc Lond 1897, 45:113-127.

63. Kraus TE, Fletcher RA: Paclobutrazol protects wheat seedlings from heat and paraquat injury - is detoxification of active oxygen involved. Plant Cell Physiol 1994, 35(1):45-52.

64. Zauberman G, Ronen R, Akerman M, Weksler A, Rot I, Fuchs Y: Postharvest retention of the red color of Litchi Fruit Pericarp. Sci Hortic-Amsterdam 1991, 47(1-2):89-97.

65. Macri F, Braidot E, Petrussa E, Vianello A: Lipoxygenase activity associated to isolated soybean plasma-membranes. Bba-Lipid Lipid Met 1994, 1215(1-2):109-114.

66. Bradford MM: A rapid and sensitive method for the quantitation of microgram quantities of protein utilizing the principle of protein-dye binding. Anal Biochem 1976, 72:248-254.

67. Arimura G, Kost C, Boland W: Herbivore-induced, indirect plant defences. Bba-Mol Cell Biol L 2005, 1734(2):91-111.

68. Howe GA, Lee GI, Itoh A, Li L, DeRocher AE: Cytochrome P450-dependent metabolism of oxylipins in tomato. cloning and expression of allene oxide synthase and fatty acid hydroperoxide lyase. Plant Physiol 2000, 123(2):711-724.

doi:10.1186/1471-2229-14-140

Cite this article as: Zebelo et al: Secretions from the ventral eversible gland of Spodoptera exigua caterpillars activate defense-related genes and induce emission of volatile organic compounds in tomato, Solanum lycopersicum. BMC Plant Biology 2014 14:140.

\section{Submit your next manuscript to BioMed Central and take full advantage of:}

- Convenient online submission

- Thorough peer review

- No space constraints or color figure charges

- Immediate publication on acceptance

- Inclusion in PubMed, CAS, Scopus and Google Scholar

- Research which is freely available for redistribution

Submit your manuscript at www.biomedcentral.com/submit 